\title{
Carbon Fibre Mesh for the Repair of Abdominal Hernias in Bovines and Caprines: A Review of Nine Clinical Cases
}

\author{
Naveen Kumar^, A. K. Sharma, S. K. Maiti, A. K. Gangwar and N. Kumar \\ Division of Surgery, Indian Veterinary Research Institute, Izatnagar-243122, Uttar Pradesh, India \\ ‘e-mail: naveen@ivri.up.nic.in \\ (Received June 11, 2007; Accepted October 4, 2007)
}

\begin{abstract}
During a 4-year period (2001-2005) 09 animals were surgically treated because of abdominal wall defects (hernia). Out of 9 animals 8 were bovines and one caprine. In each case the defect was repaired with carbon fibre mesh. All the cases were successfully treated and no complication was observed up to six months postoperatively.
\end{abstract}

Keywords : Abdominal hernias, Bovines, Carbon fibre mesh

\section{Introduction}

The surgical repair of large hernias is often difficult and a challange to clinician. In the modern surgery different types of biological and synthetic biomaterials have been used as prosthesis for the reconstruction of abdominal wall defects. However, the complications like inflammatory oedema, adhesion formation, infection, seroma formation and recurrence are quite often with the use of prosthesis.

Since the animal tissues are composed of carbon compounds hence the carbon implants may be used in repair of defects in tissues. In the past decade various forms of carbon fibres have been used to reconstruct damaged ligaments and tendons in animals as well as in human being with good results. In a study involving treatment of lesions in the superficial and deep digital flexor tendon lesions of thoroughbred race horses, carbon fibres implanted injured tendons have significantly increased tendon healing compared with both operative and non-operative standard therapy, as judged by the ability of the horses to return to racing [1]. Double strands of 6000 filaments of carbon fibres were used to reconstruct the $2.5 \mathrm{~cm}$ long defect created in superficial digital flexor tendon of experimental crossbred cow calves. Neotendon formed at the defect site was similar to normal tendon in structure $[2,3]$.

Carbon fibres were also successfully used to reconstruct the anterior cruciate ligaments in a series of 26 human patients who had suffered occupational injuries [4]. Experi- mental studies in rats revealed that it can be used for reconstruction of abdominal wall defects [5]. When carbon fibre is implanted into man or animal tissues, it is capable of producing dense fibrous tissue resembling tendon [3,6]. Carbon fibres (3000 filaments) were used to reconstruct the experimentally created full thickness linear abdominal wall defects in rabbits. Extensive fibrocellular reaction with minimal infiltration of inflammatory cells was seen at the site [7].

Based on these studies carbon fibre mesh was used in the present investigation to repair the external abdominal wall defects in clinical cases to improve the tensile strength and to stimulate the fibroplasia at the reconstruction site.

\section{Experimental}

\subsection{Animals}

Between April 2001 and March 2005, nine clinical cases were brought to the Veterinary Referral Polyclinics, Indian Veterinary Research Institute, Izatnagar, Uttar Pradesh, India for the surgical repair of external abdominal wall defects. The species, breed, sex and age of the patient, location and cause of hernia and the size of hernial ring are given in table.

Prior to surgical repair, routine clinical and haematological evaluations were carried out. The patients were off feed for 12-24 hours depending on the size of hernia and the volume of the abdomen.

\subsection{Materials}

Carbon mesh used in the present study is composed of PAN based carbon fibres (T-300-6 K Toray Industries INC.). The Tensile Strength is $3530 \mathrm{MPa}$ and Tensile Modulus is $230 \mathrm{GPa}$. Tensile Strain Elongation is $1.5 \%$. Surface treatment is given by the company which is electrochemical treatment to add some oxygen containing functional groups (carboxylic, carbonyl, hydroxyl etc.). This treatment make 
Table 1. Summary of 09 Cases of Hernias in Bovines and Caprines Repaired with Carbon Mesh

\begin{tabular}{|c|c|c|c|c|c|c|c|c|}
\hline Case No. & Species & Breed & Age & Sex & Type of hernia & $\begin{array}{l}\text { Size of hernial } \\
\text { ring }\end{array}$ & Hernia Contents & Out come \\
\hline 1. & Bovine & Crossbred calf & Seven Month & $F$ & $\begin{array}{c}\text { Congenital } \\
\text { umbilical hernia }\end{array}$ & $8 \mathrm{~cm}$ diameter & $\begin{array}{c}\text { Omentum } \\
\text { and intestines }\end{array}$ & Cured \\
\hline 2. & Bovine & Crossbred calf & Five Months & M & $\begin{array}{l}\text { Umbilical } \\
\text { hernia }\end{array}$ & $8 \times 10 \mathrm{~cm}$ & Omentum & Cured \\
\hline 3. & Bovine & Crossbred calf & Six Months & $\mathrm{F}$ & $\begin{array}{l}\text { Umbilical } \\
\text { hernia }\end{array}$ & $\begin{array}{c}7 \mathrm{~cm} \\
\text { in diameter }\end{array}$ & $\begin{array}{c}\text { Omentum } \\
\text { and intestines }\end{array}$ & Cured \\
\hline 4. & Bovine & Non descript & Ten Months & M & $\begin{array}{c}\text { Umbilical } \\
\text { hernia }\end{array}$ & $\begin{array}{c}8 \mathrm{~cm} \\
\text { in diameter }\end{array}$ & $\begin{array}{l}\text { Omentum } \\
\text { and intestines }\end{array}$ & Cured \\
\hline 5. & Bovine & Crossbred calf & Eight Months & $\mathrm{F}$ & Ventral hernia & $12 \times 10 \mathrm{~cm}$ & Intestines & Cured \\
\hline 6. & Bovine & Crossbred calf & Five Months & $\mathrm{F}$ & $\begin{array}{c}\text { Congenital } \\
\text { umbilical hernia }\end{array}$ & $7 \times 7 \mathrm{~cm}$ & Intestines & Cured \\
\hline 7. & Bovine & $\begin{array}{l}\text { Buffalo calf, } \\
\text { Non descript }\end{array}$ & Eight Months & M & $\begin{array}{c}\text { Umbilical } \\
\text { hernia }\end{array}$ & $\begin{array}{l}12 \mathrm{~cm} \\
\text { in diameter }\end{array}$ & Intestines & Cured \\
\hline 8. & Bovine & $\begin{array}{l}\text { Buffalo calf, } \\
\text { Non descript }\end{array}$ & Eight Months & $\mathrm{F}$ & Ventral hernia & $\begin{array}{c}9 \mathrm{~cm} \\
\text { in diameter }\end{array}$ & $\begin{array}{l}\text { Omentum } \\
\text { and Intestines }\end{array}$ & Cured \\
\hline 9. & Caprine & Non descript & Three years & M & Ventral hernia & $\begin{array}{c}6 \mathrm{~cm} \\
\text { diameter }\end{array}$ & $\begin{array}{c}\text { Omentum } \\
\text { and intestines }\end{array}$ & Cured \\
\hline
\end{tabular}

the surface of carbon fibres hydrophilic, so these functional groups react with other molecules containing $-\mathrm{OH},-\mathrm{COOH}$ and $-\mathrm{NH}_{2}$ in the end chains. Carbon fibres are also given sizing for hand ability of the carbon fibre tow which is generally $0.8 \%$ to $1 \%$ Epoxy resin. Before implantation the carbon mesh was cut in the desired shape and size and the free ends stitched. The mesh was rinsed in acetone for 2 minutes to remove the epoxy resin coating. Then mesh was washed in normal saline and autoclaved before implantation in the animals.

\subsection{Surgical procedure}

The animals were positioned in dorsal recumbency. The surgical field was shaved and subsequently prepared for aseptic surgery. An elliptical skin incision was given over the external hernial sac. The internal hernial sac was bluntly dissected and freed down to the hernial ring. The internal hernial sac was opened and the hernial ring was repaired with carbon fibre mesh using mattress suture pattern (Fig. 1 and 2). After closing the hernial ring with carbon fibre mesh the sac and subcutaneous tissue was repaired with polyglycolic acid suture material (I-COL: Stericat Gutstrings

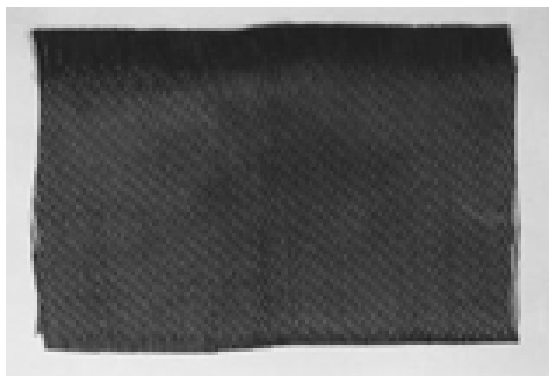

Fig. 1. Carbon mesh.
(P) Ltd., E-25, B-1, Extension, MCIE, Mathura Road, New Delhi, India). The skin incision was closed with simple interrupted mattress sutures using monofilament polyamide suture material (STERILON: Stericat Gutstrings (P) Ltd., E25, B-1, Extn, MCIE, Mathura Road, New Delhi, India) (Fig.3 to 14).

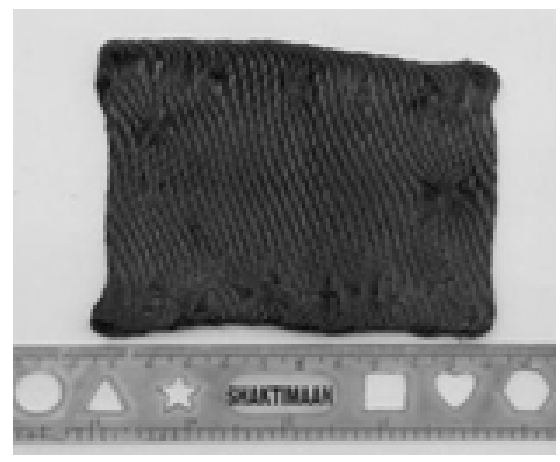

Fig. 2. Finish appearance of carbon mesh.

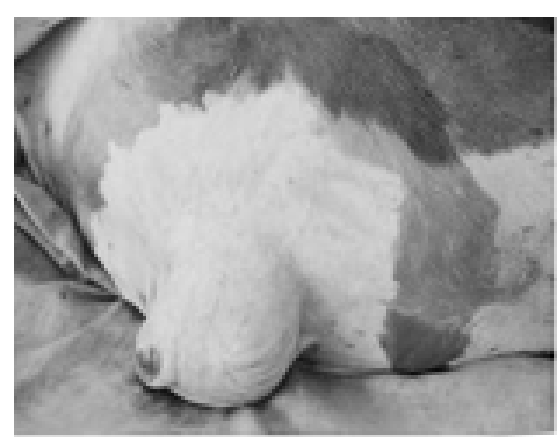

Fig. 3. A crossbred calf showing large umbilical hernia (Case no.2). 


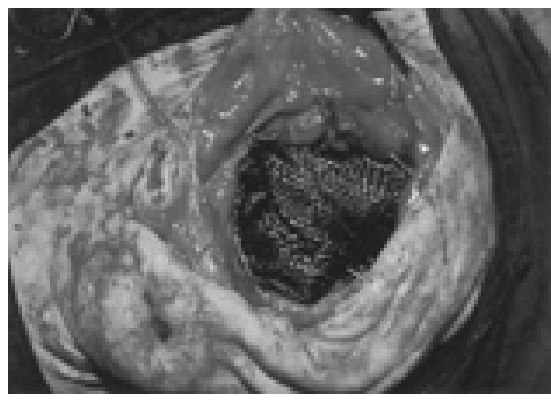

Fig. 4. Repair of hernia with carbon mesh.

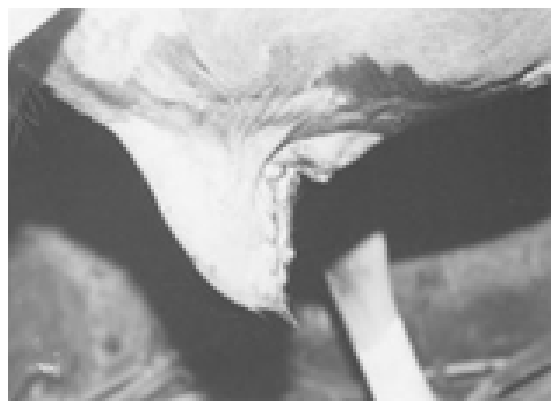

Fig. 5. Post operative appearance after repair with carbon mesh.

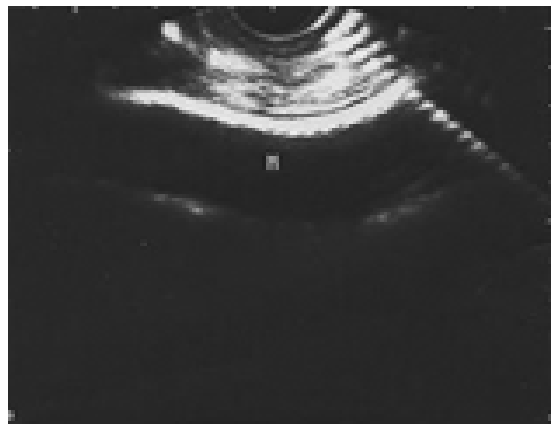

Fig. 6. Ultrasonographic view showing placement of mesh.

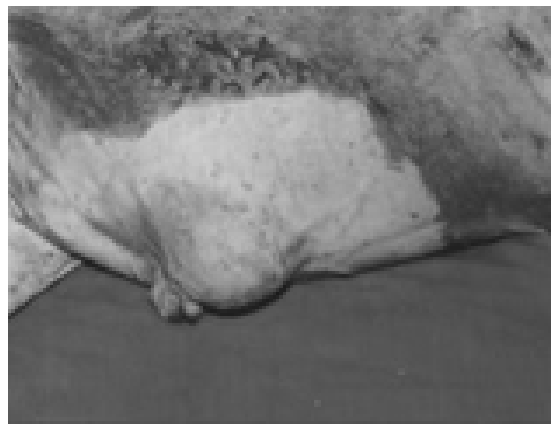

Fig. 7. A crossbred calf showing large umbilical hernia (Case no.4).

\subsection{Postoperative care}

Postoperative care was consisted of administration of antibiotics (INTACEF: Intas Pharmaceuticals Ltd., Chinub-

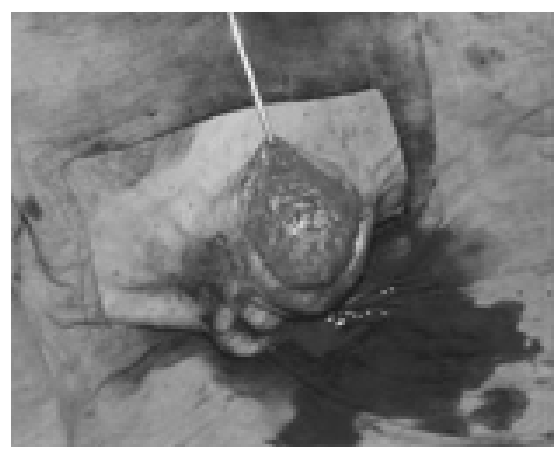

Fig. 8. An elliptical incision to open the hernial sac.

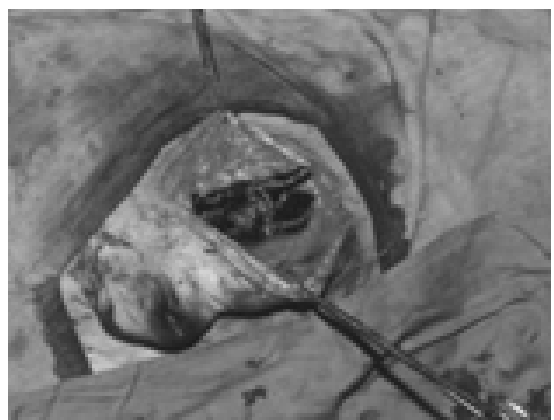

Fig. 9. Repair of hernia with carbon mesh.

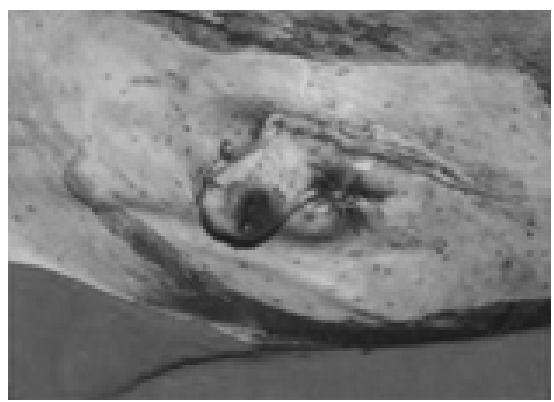

Fig. 10. Post operative appearance after repair with carbon mesh.

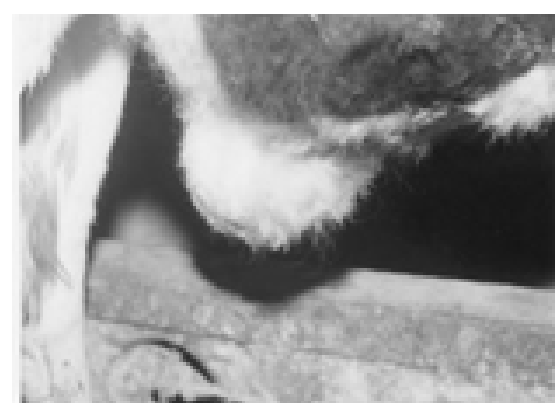

Fig. 11. A crossbred heifer showing large ventral hernia (Case no. 5).

hai Centre, Ashram Road, Ahmedabad, Gujrat, India) and analgesic (MELONEX: Intas Pharmaceuticals Ltd., Chinubhai Centre, Ashram Road, Ahmedabad, Gujrat, India) and 


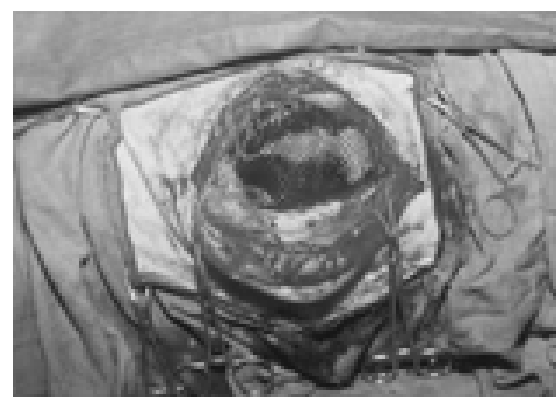

Fig. 12. Reconstruction of hernia with carbon mesh.

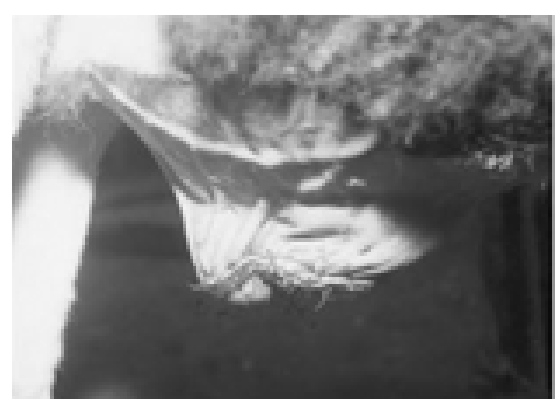

Fig. 13. Immediate post operative view after repair with carbon mesh.

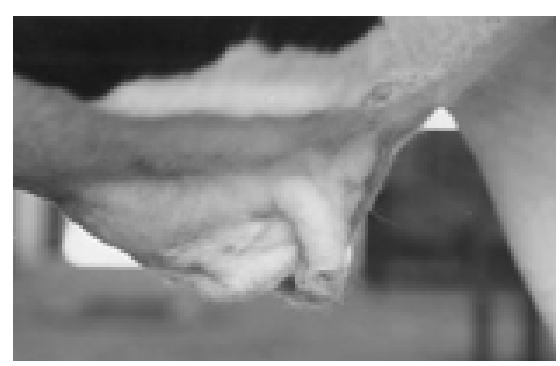

Fig. 14. Post operative view after 2 months of repair with carbon mesh.

daily dressing of suture line with $5 \%$ povidone iodine (BECTOSEPT Solution: Ranbaxy Laboratoies Limited, $11^{\text {th }}$ Floor, Devika Tower, 6 Nehru Palace, New Delhi, India). Feed concentrates were offered in normal quantities, but the roughage was restricted for first week and then gradually placed on the normal diet. The skin sutures were removed on $10^{\text {th }}$ to $15^{\text {th }}$ postoperative day depending upon the wound condition.

To evaluate the long-term results a telephonic survey was carried out. The owners were asked about status of the repair site, patient's condition, final cosmetics and functional results of the surgery.

\section{Results and Discussion}

The animals were observed daily upto day 15 till the skin sutures removed. The recovery in all the nine cases was uneventful with in time period of 10 to 15 days. The animals were alert and healthy throughout the observation period and reflected the freedom from any untoward reaction and completion. Mild inflammatory swelling was observed at the incision line which was completely subsided by $15^{\text {th }}$ postoperative day. No seroma formation at the repair site was observed at the time of removal of skin sutures. All the wounds healed by first intention healing. No recurrence was seen in a follow up period of 6 months in any case. A thick fibrous healing tissue was palpated at the site. It indicates that carbon fibres were not only tolerated by the animals but it stimulates the deposition of collagen and fibrous tissue at the healing site. Stronger the fibrous tissue at the site, recurrence chances were lesser. The clinical parameters viz. rectal temperature, heart rate and respiration rate were found within normal limits. No significant change was observed in haematological parameters. The total leucocyte count, differential leucocyte count, hemoglobulin and pack cell volume values were found with in normal limits.

Foster et al. [6] reported that if the implant is under functioning load as in the present case, the fibroblastic potency prevails and abundant fibrous tissue is produced and later organized in bundles. Similarly, carbon fibres mesh used in the present study is not only well tolerated by animal tissues, but also strong stimulatory effect on collagen formation was seen. Various reports regarding its use in the reconstruction of tendon and ligaments in experimental animals $[2,3,8,9,10]$ as well as in human being $[11,12,13]$ are documented in the literature.

Carbon fibres have been used for the repair of experimental large abdominal incisional hernias in sheep. The carbon fibres were well tolerated by animals and no herniation was reported in 20 sheep repaired with carbon fibres. There was gradual invasion of fibres by collagenous tissue and thus a transition from one to the other of the streee of maintaining the abdominal wall intact [14].

A filamentous polylactic acid-carbon tissue mesh and marlex mesh was evaluated in repairing a large defect of the abdominal wall in a rat model. The polylactic acid carbon tissue mesh acted as a biocompatible scaffold and no wound infection or seroma collection postoperatively was noted. It induces more marked fibrotic response and a lesser inflammatory response as compared to marlex mesh [15]. In an another experimental study Morris et al. [5] repaired fascial defects in dogs using carbon fibres. Bilateral defects (1 cm square) were made in the fascia of the back and mechanical strength and stiffness at the sites were measured 3-12 months after operation. Defects repaired with carbon fibres were significantly stronger 12 months after operation compared with defects repaired with polypropylene mesh and unrepaired defects. Cameron and Taylor [16] repaired the large abdominal wall defects with marlex mesh and an open darm of filamentous carbon in Porton-Wister rats. The histopathological observations at different time interval revealed striking difference. Marlex had induced a chronic 
inflammatory response with disorganized collagen, whereas, the carbon was not only well tolerated but acted as a scaffold for well organized and oriented collagen. Thus was concluded that carbon mesh acts as biocompatible material and significantly increases mechanical strength at the repair site. It stimulated fibroplasias, resulted in strong fibrous reaction at the site. Experimental results in animals have been reported but on perusal in literature no report was found using carbon fibre mesh for the repair of external abdominal hernias in clinical cases of large animals.

\section{Conclusions}

In the present study carbon fibre mesh have been used for the repair of external abdominal wall defects/hernias in 09 clinical cases of bovines and caprines having the hernial ring size ranged from $6 \mathrm{~cm}$ to $15 \mathrm{~cm}$ in diameter with good results. This is probably the first report in which carbon fibre mesh has been successfully used for the repair of abdominal wall defects in clinical cases.

\section{Acknowledements}

The authors are thankful to Dr T. L. Dhami and Dr. R. B. Mathur of Carbon Technology Unit, Engineering Materials Division, National Physical Laboratory, New Delhi, for their kind support and providing the carbon fibre mesh used in this work.

\section{References}

[1] Reed, K. P.; Berg, S. S.; Vanden, R. A.; Albright, J. A.;
Casey, H. W.; Marino, A. A. Journal of Equine Veterinary Science 1994, 14, 371.

[2] Naveen Kumar; Sharma, A. K.; Singh, G. R.; Gupta, O. P. J. Veterinary Medicine Series A 2002, 49, 161.

[3] Naveen Kumar; Sharma, Ashok K.; Sharma, Anil K.; Satish Kumar. J. Veterinary Medicine Series A 2002, 49, 269.

[4] Demmer, P.; Fowler, M.; Marino, A. A. Clinical Orthopaedics 1991, 271, 225.

[5] Morris, D. M.; Hindman, J.; Marino, A. A. J. Surgical Research 1998, 80, 300.

[6] Forster, I. W.; Ralis, Z. A.; Mckibbin, B.; Jenkins, D. H. R. Clinical Orthopaedics 1978, 131, 299.

[7] Gangwar, A. K. "Biomaterials in the repair of abdominal wall defects in rabbits and their clinical application", MVSc Thesis, Deemed University, Indian Veterinary Research Institute, 2002, Izatnagar, Uttar Pradesh, India.

[8] Brown, M. P; Pool, R. R. J. American Veterinary Medical Association 1983, 82, 956.

[9] Parsons, J. R., Bhayani, S., Alexander, H.; Weiss, A. B. Clinical Orthopaedics and Related Research 1985, 196, 69.

[10] Bredin, K. Irish Veterinary Journal 1986, 40, 139.

[11] Rushton, N., Dandy, D. J.; Naylor, C. P. E. J.Bone and Joint Surgery 1983, 65-B, 308.

[12] Layson, R. L., Channon, G. M., Jenkins, D. H. R.; Ralis, Z. A. J. Bone and Joint Surgery 1984, 66B, 196.

[13] Neugebauer, R. and Burri, C. Akteul Prob Chir Orthopaedics 1983, 26, 96.

[14] Johnson-Nurse, C.; Jenkins, D. H. R. British Journal of Surgery 1980, 67, 135.

[15] Greenstein, S. M., Murphy, T. F.,Rush Jr., B. F.; Alexander, H., American Journal of Surgery 1986, 151, 635.

[16] Cameron, A. E. P.; Taylor, D. E. M. British Journal of Surgery 1979, 72, 648. 